\title{
Structural Diversity of Woody Species in the Senegalese Semi-Arid Zone-Ferlo
}

\author{
Ousmane Ndiaye $^{1}$, Aly Diallo ${ }^{1}$, Stephen A. Wood ${ }^{2}$, Aliou Guisse ${ }^{1,3^{*}}$ \\ ${ }^{1}$ Department of Plant Biology, Faculty of Science and Technology, Université Cheikh Anta Diop, Dakar, Sénégal; ${ }^{2}$ Department of \\ Ecology, Evolution, and Environmental Biology, Columbia University, New York, USA; ${ }^{3}$ Tessekere International Human-En- \\ vironment Observatory, Cheikh Anta Diop University, Dakar, Sénégal. \\ Email: ${ }^{*}$ alguisse@orange.sn, *aliou.guisse@ucad.edu.sn
}

Received November $18^{\text {th }}, 2013$; revised January $23^{\text {rd }}, 2014$; accepted February $21^{\text {st }}, 2014$

Copyright (C) 2014 Ousmane Ndiaye et al. This is an open access article distributed under the Creative Commons Attribution License, which permits unrestricted use, distribution, and reproduction in any medium, provided the original work is properly cited. In accordance of the Creative Commons Attribution License all Copyrights @ 2014 are reserved for SCIRP and the owner of the intellectual property Ousmane Ndiaye et al. All Copyright (C) 2014 are guarded by law and by SCIRP as a guardian.

\section{ABSTRACT}

The combined effects of climate change and human pressure have led to the progressive degradation of natural resources in semi-arid regions. Woody taxa in these regions play an important role in the functioning and services provided by semi-arid savannah by serving as forage for both domestic and non-domestic grazers. Maintaining the functioning of semi-arid savannas thus requires understanding the dynamics of these communities of woody taxa and their responses to exogenous forces, such as climate. To better understand the dynamics of woody taxa in semi-arid environments we collected dendrometric characteristics from five field sites along an environmental gradient in the Ferlo region of central Senegal. Density and basal area were found to be greater in the northern part of the zone, contrasted with the distance between individuals and crown cover, which is greater in the southern part of the zone. Stand structure estimated from the distribution according to height and diameter at breast height shows a preponderance of individuals in the shrub layer, although with a significant representation of the tree layer in southern Ferlo. Stand regeneration was better in the south and less effective in the north. There was a trend towards the rejuvenation of populations belonging to the dominant species. There were only three species for which degradation was not apparent (Balanites aegyptiaca, Acacia raddiana and Dalbergia melanoxylon), all of which have important ethnobotanical uses, suggesting that human use of taxa can play an important role in preventing degradation. Three distinct groups of woody taxa were found to correspond to gradients of precipitation, topography, and human land use pressure. Our results suggest an important role in the management and reintroduction of woody species in the Sahel and the regulation of pastoral techniques necessary for the rehabilitation of the agro-pastoral zone of Senegal.

\section{KEYWORDS}

Woody Taxa; Senegal; Ferlo; Drylands; Community Structure

\section{Introduction}

The combined effects of climate change and human pressure have led to the progressive degradation of natural resources in semi-arid regions. Woody taxa in these regions play an important role in the functioning and services provided by semi-arid savannah by serving as forage for both domestic and non-domestic grazers. Maintaining the functioning of semi-arid savannas thus re-

${ }^{*}$ Corresponding author. quires understanding the dynamics of these communities of woody taxa. The Sahel is one of the largest drylands on the planet and one that supports high levels of biodiversity and dense human populations.

In the Sahel, pastoral management of grazing occurs over large surfaces of land and uses natural forage species $[1,2]$. This pastoral system functions according to two distinct modes. During the rainy season, pastureland is mainly dominated by herbaceous taxa, while in the dry season woody taxa are more dominant and are used as 
livestock forage. As in most pastoral zones, woody taxa resources play an important role in the nourishment of livestock and meeting the needs of the human communities that tend to those livestock [3]. However, these resources have been progressively degraded over the last 40 years, driven by droughts, such as the large drought of the 1970s, and multiple forms of human activity. This degradation has been found to be associated with the loss of certain taxa as well as the expansion of others [4]. Simultaneously, the average density of woody taxa in the Ferlo zone has clearly diminished over the course of the last several decades [5] with consequences for the quality of soil through increased erosion. Facing this situation, strategies are much needed to rehabilitate these degraded ecosystems. One such strategy is a rotational grazing approach promoted by the Senegales government to facilitate the regeneration of vegetation during years in which climate conditions allow for growth and re-establishment [6]. The government has also promoted efforts to plant trees across the southern border of the Sahara desert, a pan-African project known as the Green Wall Initiative, to prevent the southwards encroachment of the desert. All of these projects have been developed with the aim of improving natural resource stocks, but have little evidence of success. In order for these strategies to work, it will be necessary to put in place a system of sustainable management that emphasizes the protection of woody taxa on fragile and vulnerable soils. This sustainable management requires familiarity with the precise ecological conditions under which these taxa perform best. This study aims to document the conditions under which the structural diversity of woody taxa changes in the Ferlo zone in order to facilitate more appropriate management strategies.

\section{Materials and Methods}

\subsection{Study Zone}

The Ferlo zone is located in the West African Sahel between $15^{\circ}$ and $16^{\circ} 30$ north and $13^{\circ} 30$ and $16^{\circ}$ west. It extends from the valley of the Senegal River, in the north, to the limits of edge of the Peanut Basin in the south, covering more than $60,000 \mathrm{~km}^{2}$ [7].

Administratively, the Ferlo covers the entire region of Matam as well as part of the regions of Saint-Louis and Louga (Figure 1). The study was conducted in five particular locations in the Ferlo: Widou, Téssékéré and Labgar in the north and Kamb and Déali in the south. The selection of these particular sites was motivated by two rainfall gradients: one that runs East-West (including Widou, Téssékéré and Labgar) and another that runs North-South (including Widou, Kamb and Déali) (Figure 1).

The climate of the Ferlo region is similar to much of the Sahel and characterized by two main seasons: a dry season that lasts nine months from October to June, and a rainy season of three months. Total annual rainfall is both low and highly variable, with an average of 422.6 mm per year from 1951-2004, but with a standard deviation of $126.8 \mathrm{~mm}$ per year [8]. Mean annual temperature oscillates around $27.7^{\circ} \mathrm{C}$ and fluctuates between a maximum average of $30.2^{\circ} \mathrm{C}$ in the month of October and a minimum of $24.5^{\circ} \mathrm{C}$ in the month of January [9].

Pedologically, the study zone is part of the sandy Ferlo region characterized by a succession of dunes and hilly low-lying areas that contain a different soil type than found on the tops of the dunes or at the bottom of a hill [10]. The low-lying areas effectively have a ratio of clay that is greater than at the tops of the dunes.

The study site also contains two types of hydrological layers: one which is deep aquifers from the Mastricht and Eocene and another which is less deep and comes from the terminal continental and quartneary aquifers [11].

\subsection{Woody and Herbaceous Species Inventory}

The sampling strategy consisted of randomly locating 90 experimental plots of an area of $2500 \mathrm{~m}^{2}$. Placement of the plots was done using the 3-4-5 method to find right angles. This surface corresponds to the minimal area needed for study of woody vegetation in the Sahel [12, 13]. In each experimental plot, all individuals were identified that had a basal circumference greater than $10 \mathrm{~cm}$. Dendrometric measurements were also taken, including circumference at the base of the trunk, crown diameter, and total height. The distance between individuals was measured using the nearest-neighbor method [14].

Individuals with a basal circumference less than $10 \mathrm{~cm}$ were listed in order to determine the regeneration rate of species populations related to both seed and seeling regeneration. Individuals that were cut or standing dead were also listed in order to evaluate rates of mortality and human impact. Species identification was conducted using previously published guides to the flora of Senegal [15]. Certain species identifications were updated using more recent classification schemes [16].

\subsection{Data Analysis}

The structure of the woody taxa populations were analyzed using important structural characteristics of the populations, including density, ground cover, crown area, and the distribution of individuals by height and thickness. Density is defined as the abundance of a species within a site, where abundance is given by the number of individuals. Theoretically, density can be expressed as the average distance between individuals (dmoy), given as [17]: 


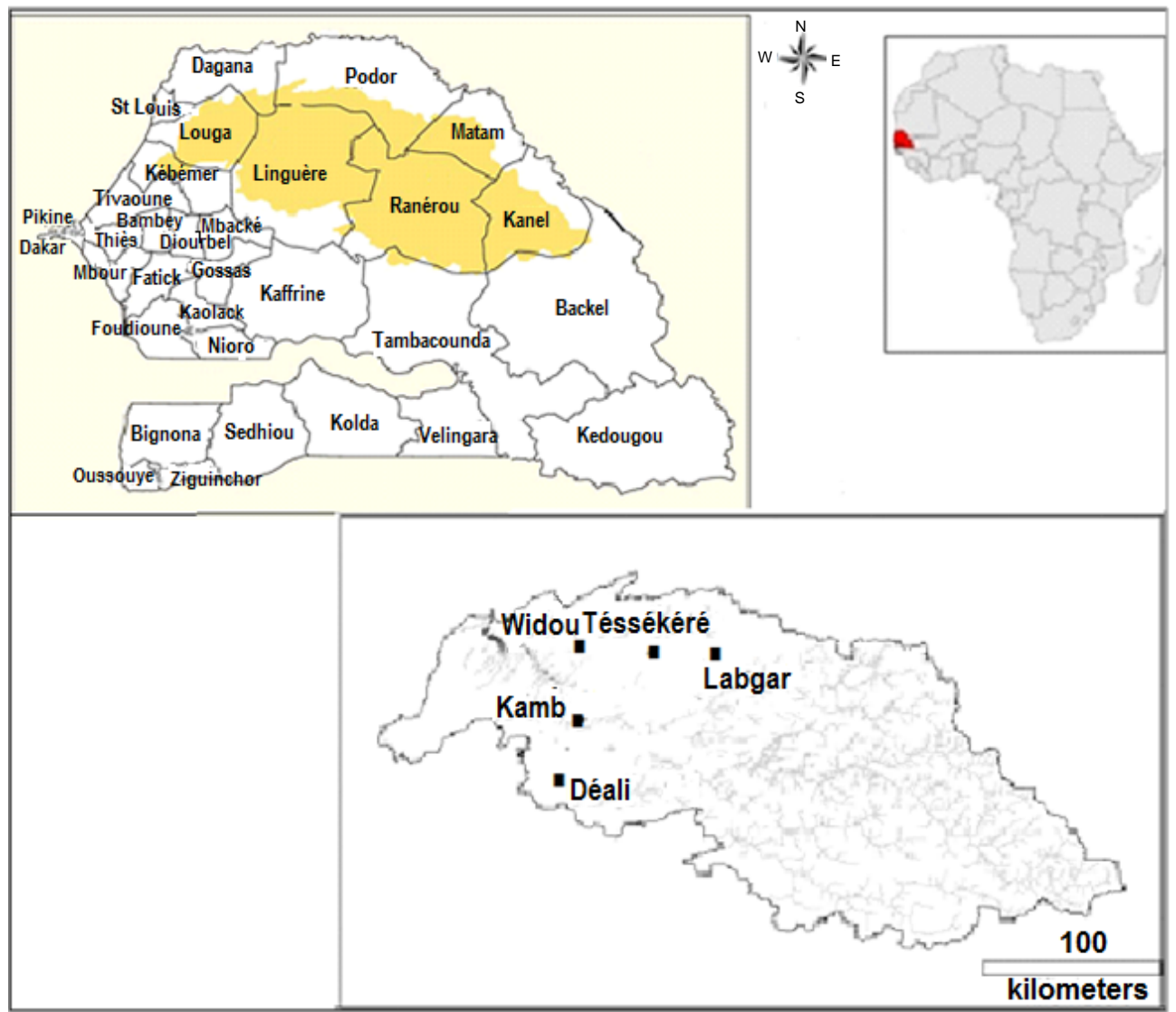

Figure 1. Site locations in the Ferlo zone in central Senegal.

$$
\text { Theoretical density }(\text { ind } / h a)=\frac{10,000}{(d m o y)^{2}}
$$

The dominance of a species is given as its ground surface area occupied in meters per hectare [18]. The ground surface area of each species (Ste) is found by adding the basal circumference of all of the individuals within that species that are at least $10 \mathrm{~cm}$. Crown cover corresponds to the surface on the ground covered by the crown in meters per hectare. Similarly to ground cover, species crown cover $(S c)$ is defined as the sum of the crown cover for each individual:

$$
\text { Sc }=\sum \frac{\pi D^{2}}{4}
$$

where $D$ represents the average crown diameter for all of the individuals.

Relative densities were also calculated by circumference and height class to determine the distribution of individuals according to these variables. The distribution of individuals according to circumference allows for evaluation of the horizontal structure of the community and populations; the vertical structure, similarly, can be assessed by the distribution of individuals by height. Individuals are classified as trees if their height is greater than seven meters and are classified as shrubs if less than seven meters $[19,20]$. To test for significant pairwise differences between sites for the various measures of population structure, Welch's 2-sample t-tests were computed using XLSTAT 6.19. All analyses were conducted using Microsoft Excel 2007.

\section{Results}

\subsection{Population Density}

Over the entire study area, 4055 individuals were listed, which corresponds to an overall density of 180.22 individuals per hectare, distributed across all taxonomic groups. Broken down by site, 1296 individuals were identified in Widou, 1122 in Téssékéré, and 636 in Labgar, 475 in Kamb, and 524 in Déali, with densities being 172.8, 149.6, 84.8, 63.3, and 69.9 respectively (Table 1 ).

The most abundant species were Balanites aegyptiaca (L.) Delile (1311 individuals), Calotropis procera (Aiton) W.T.Aiton (1176 individuals) and Boscia senegalensis (Pers.) Lam. ex Poir. (720 individuals). These species cumulatively represent 88.3 percent of the individuals found in the study area, with per hectare densities of 35, 31.4 , and 19.2 individuals respectively. The mean distance between individuals is $5.2 \mathrm{~m}$ in Widou, $5.0 \mathrm{~m}$ in 
Table 1. Structural characteristics of the study sites and the Ferlo zone.

\begin{tabular}{|c|c|c|c|c|c|c|}
\hline & $\begin{array}{l}\text { Study } \\
\text { Zone }\end{array}$ & Widou & Téssékéré & Labgar & Kamb & Déali \\
\hline Observations & 4053 & 1296 & 1122 & 636 & 475 & 524 \\
\hline $\begin{array}{l}\text { Real density (ind/ha) } \\
\text { Standard deviation }\end{array}$ & $\begin{array}{c}108.08 \\
49.79\end{array}$ & $\begin{array}{c}172.80 \\
37.65\end{array}$ & $\begin{array}{c}149.60 \\
33.08\end{array}$ & $\begin{array}{l}84.80 \\
18.67\end{array}$ & $\begin{array}{l}63.33 \\
16.21\end{array}$ & $\begin{array}{l}69.87 \\
16.62\end{array}$ \\
\hline $\begin{array}{l}\text { Theorical density (ind/ha) } \\
\text { Standard deviation }\end{array}$ & $\begin{array}{c}234.52 \\
7.21\end{array}$ & $\begin{array}{c}371.25 \\
9.48\end{array}$ & $\begin{array}{c}404.84 \\
5.97\end{array}$ & $\begin{array}{c}247.22 \\
6.79\end{array}$ & $\begin{array}{c}145.86 \\
7.73\end{array}$ & $\begin{array}{c}162.28 \\
7.24\end{array}$ \\
\hline $\begin{array}{l}\text { Surface area (m²/ha) } \\
\text { Standard deviation }\end{array}$ & $\begin{array}{c}20.53 \\
0.71\end{array}$ & $\begin{array}{l}5.06 \\
0.61\end{array}$ & $\begin{array}{l}3.85 \\
0.28\end{array}$ & $\begin{array}{l}4.63 \\
0.61\end{array}$ & $\begin{array}{l}3.62 \\
0.89\end{array}$ & $\begin{array}{l}3.37 \\
0.45\end{array}$ \\
\hline $\begin{array}{l}\text { Total coverage }\left(\mathrm{m}^{2} / \mathrm{ha}\right) \\
\text { Standard deviation }\end{array}$ & $\begin{array}{c}7304.93 \\
361.00\end{array}$ & $\begin{array}{c}2008.09 \\
211.30\end{array}$ & $\begin{array}{c}1121.43 \\
61.85\end{array}$ & $\begin{array}{c}1145.47 \\
85.82\end{array}$ & $\begin{array}{c}1544.91 \\
145.00\end{array}$ & $\begin{array}{c}1485.02 \\
257.50\end{array}$ \\
\hline
\end{tabular}

Téssékéré, $6.4 \mathrm{~m}$ in Labgar, $8.3 \mathrm{~m}$ in Kamb, and $7.8 \mathrm{~m}$ in Déali, with theoretical densities being 371.25, 404.84, 247.22, 145.86, and 162.28 trees per hectare, respectively. The theoretical densities are largely greater than actual densities, regardless of the site. This tendency has also been noted across the entire study region (Table 1).

\subsection{Population Coverage}

Basal coverage evaluated by surface area is $20.53 \mathrm{~m}^{2} \cdot \mathrm{ha}^{-1}$ for the entire study zone. Coverage area was found to be greater in Widou and Labgar and lower in Téssékéré, Kamb and Déali. However, the values for the surface area between these two stratifications are not significantly different (Table 1 ). The species dominating surface area are $B$. aegyptiaca $\left(6.7 \mathrm{~m}^{2} \cdot \mathrm{ha}^{-1}\right)$, Adansonia digitata L. $\left(4.3 \mathrm{~m}^{2} \cdot \mathrm{ha}^{-1}\right)$, C. procera $\left(1.7 \mathrm{~m}^{2} \cdot \mathrm{ha}^{-1}\right)$ and $B$. senegalensis $\left(1.5 \mathrm{~m}^{2} \cdot \mathrm{ha}^{-1}\right)$. These species make up $69.2 \%$ of basal area coverage.

Crown cover is $7305 \mathrm{~m}^{2} \cdot \mathrm{ha}^{-1}$ for the entire study region. Divided by sub-sites, this is broken into 2008 $\mathrm{m}^{2} \cdot \mathrm{ha}^{-1}$ in Widou, followed by Kamb $\left(1545 \mathrm{~m}^{2} \cdot \mathrm{ha}^{-1}\right)$, Déali $\left(1485 \mathrm{~m}^{2} \cdot \mathrm{ha}^{-1}\right)$, Labgar $\left(1146 \mathrm{~m}^{2} \cdot \mathrm{ha}^{-1}\right)$ and Téssékéré (1121 $\mathrm{m}^{2} \cdot \mathrm{ha}^{-1}$ ), which makes up 27.49, 21.15, $20.33,15.68$, and 15.35 percent of total crown cover area. Balanites aegyptiaca, C. procera and B. senegalensis cover more than half of total surface area in Widou (69.21\%), Déali (65.38\%) and Labgar (51.05\%). These species only cover, however, 39.44 and 38.79 percent respectively of the area in Téssékéré and Kamb.

\subsection{The Distribution of Individuals by Circumference}

The demographic structure of populations, illustrated by the distribution of individuals according to size classes across all species, shows a roughly log-normal distribution in Widou, Téssékéré and Labgar (north Ferlo) and a uniform distribution for the other sites (Figure 2).

The overall distribution for the study sites appears log-normal. This pattern holds when considering independently the most abundant species (Figure 2). In the
Ferlo in general, and especially in the more northern parts, more than 50 percent of the populations of woody taxa are individuals with a circumference greater than 40 $\mathrm{cm}$. In the southern part of the study region, 52 percent of the individuals at Kamb and 35 percent of the individuals at Deali have a circumference greater than $60 \mathrm{~cm}$ (Figures 2(e) and (f)).

\subsection{The Distribution of Individuals According to Height}

The distribution of woody taxa by height follows a unimodal distribution in the northern part of the study region. In these sites, the overall community as well as the dominant species is predominantly (more than 60\%) made up of individuals with a height of less than four meters (Figures 3(b), (c) and (d). The same pattern is seen when considering the entire study region (Figure 3(a)). By contrast, in the southern part of the region, the distribution of individuals by height is slightly irregularly distributed, with a majority of individuals of small size (Figures 3(e) and (f)). Nevertheless, individuals with a height greater than seven meters are also well represented in Kamb and Déali, with 36 and 25 percent of the populations, respectively.

\subsection{Growth Relationships between Height and Circumference}

The allometric growth relationships that exist between height and circumference (at $0.3 \mathrm{~m}$ from the ground) in the study region (Figure 4) are expressed as logarithmic functions. This shows that there is not a clear linear relationship between height growth and circumference. Linear regression, however, shows that in the northern part of the study region, there is a strong relationship between height and circumference, with regression coefficients greater than 0.6 . This shows similarly that in this area of the study region, height does not grow indefinitely depending on diameter. The height of trees stabilizes at around $16 \mathrm{~m}$, while the diameter can continue to grow (Figure 4). 


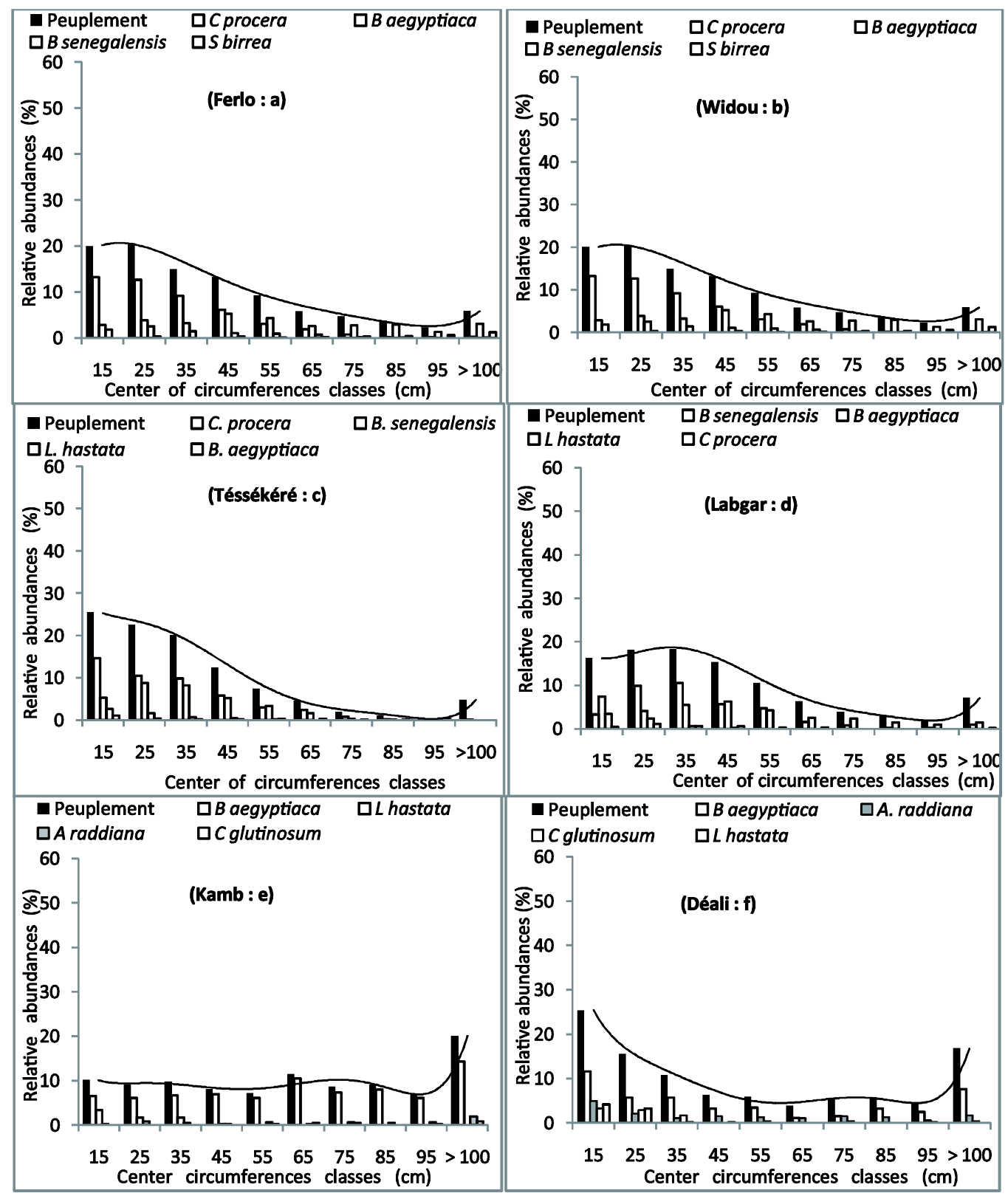

Figure 2. Structure of individuals according to circumference, representing the most abundant species in the study sites.

\subsection{Regeneration of Populations}

The distribution of young plants in the study region (Figure 5(a)) shows that woody species have regenerated at greater than 45 percent. These young plants mainly contain individuals of the species B. aegyptiaca (27.76\%), Leptadenia hastata (Pers.) Decne. (25.86\%), C. procera (25.15\%), B. senegalensis (12.43\%) and A. raddiana (3.52\%). In Widou, where the woody population regenerates at $39.47 \%$ (Figure 5(b)), the young plants are mainly of the species $C$. procera $(48.63 \%), B$. aegyptiaca (22.60\%), L. hastata (14.67\%), B. senegalensis (9.47\%) and Sclerocarya birrea (A. Rich.) Hochst (2.48\%). The same trend is seen in Téssékéré (Figure 5(c)) where young plants make up $44.26 \%$ of total population and the most abundant are C. procera (46.01\%), B. senegalensis (24.13\%), L. hastata (18.97\%), B. aegyptiaca $(3.59 \%)$ and $A$. raddiana $(1.12 \%)$. In Labgar (Figure 5(d)), the species that regenerate the most are: L. hastata (33.78\%), B. senegalensis (29.05\%), B. aegyptiaca (22.30\%), C. procera $(7.66 \%)$ and A. raddiana (5.63\%). Regeneration rates are higher in the southern part of the study zone. Young plants represent $50.61 \%$ of woody populations in Kamb and $60.68 \%$ in Déali. In these locations the species that regenerate best are B. aegyptiaca (59.40\% and $41.71 \%$ ) and L. hastata $(37.24 \%$ and $32.60 \%)$ respectively in Kamb and Déali (Figures 5(e) and (f)). 


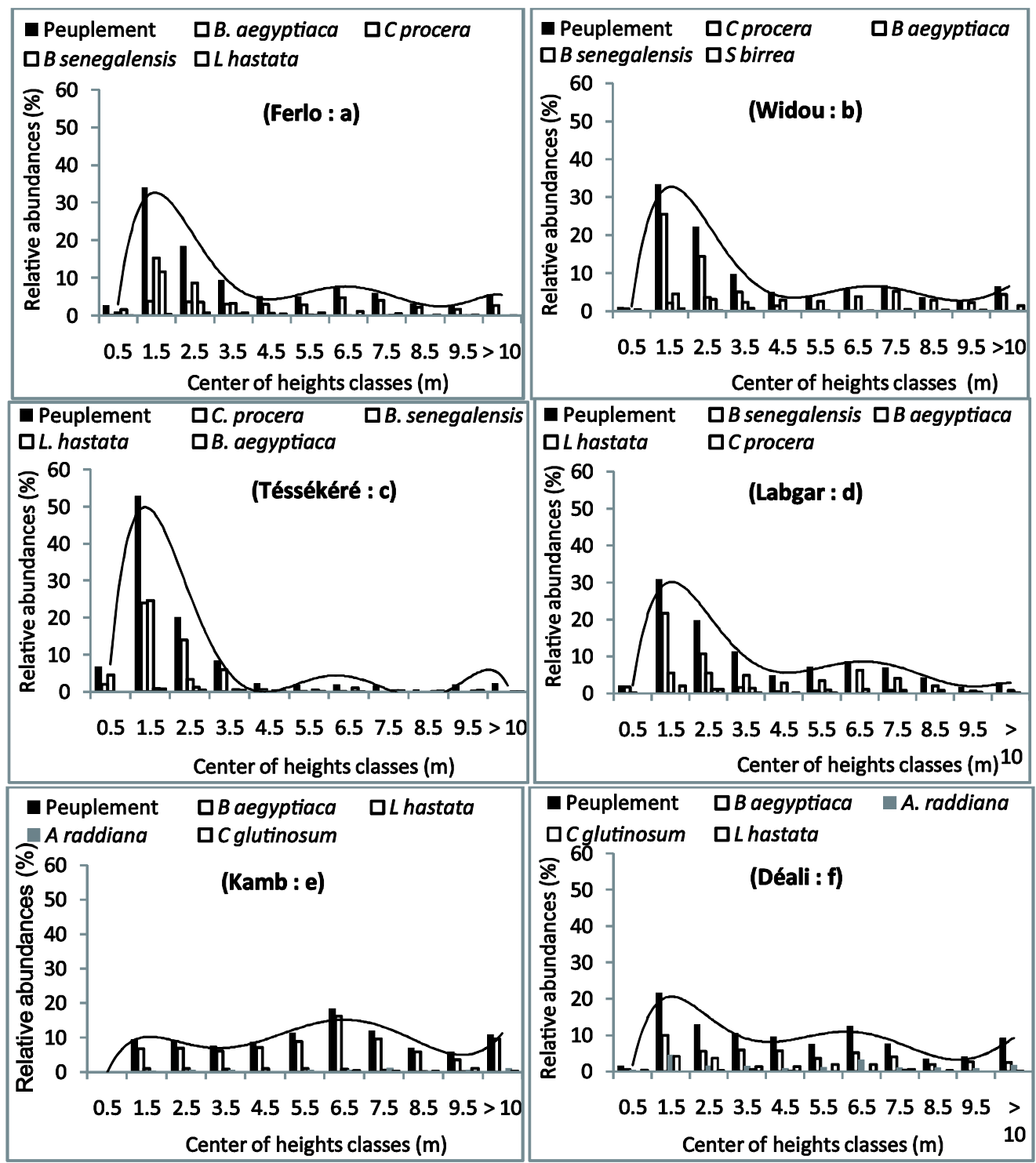

Figure 3. Structure of individuals according to height, representing the most abundant species in the study sites.

\subsection{Degradation of Woody Populations and Human Impacts}

The rate of human impacts on the woody populations of the Ferlo study region varies as a function of particular sites (Figure 6). In the entire study region, the rate of mortality is lower than one percent. C. procera has the highest rate of mortaility (60\%) with the next highest being $B$. aegyptiaca (58.33\%) and $A$. raddiana (29.16\%), the latter of which is predominantly exploited by cutting (Figure 6(a)). In Widou and Téssékéré, mortality is also dominated by C. procera, making up $64 \%$ and $78.48 \%$ respectively. In these sites, exploitation by cutting only applies to B. aegyptiaca (in Widou) and D. melanoxylon (in Téssékéré) (Figures 6(b) and (c)). In Labgar, there were no noted events of mortality, but exploitation by pruning was common for B. senegalensis (66.67\%). In the southern section of the study zone, cutting is more clearly on B. aegyptiaca with $66.67 \%$ of individuals affected in Kamb and $61.11 \%$ of individuals affected in Déali. The second-most impacted species is $L$. hastate (33.33\%) in Kamb and A. raddiana (38.89\%) in Déali (Figures 6(e) and (f)). Mortality in Déali was exclusively noted for B. aegyptiaca, but was noted in Kamb for A. raddiana, B. aegyptiaca and $S$. birrea with a similar rate of around 30\% (Figure 6(e)).

\section{Discussion}

The assessment of the structural diversity of a stand especially a population, is of great interest for the sustainable management of forest resources by evaluating readily available and future planning of the samples [21]. This distribution can be used to predict the threat of 


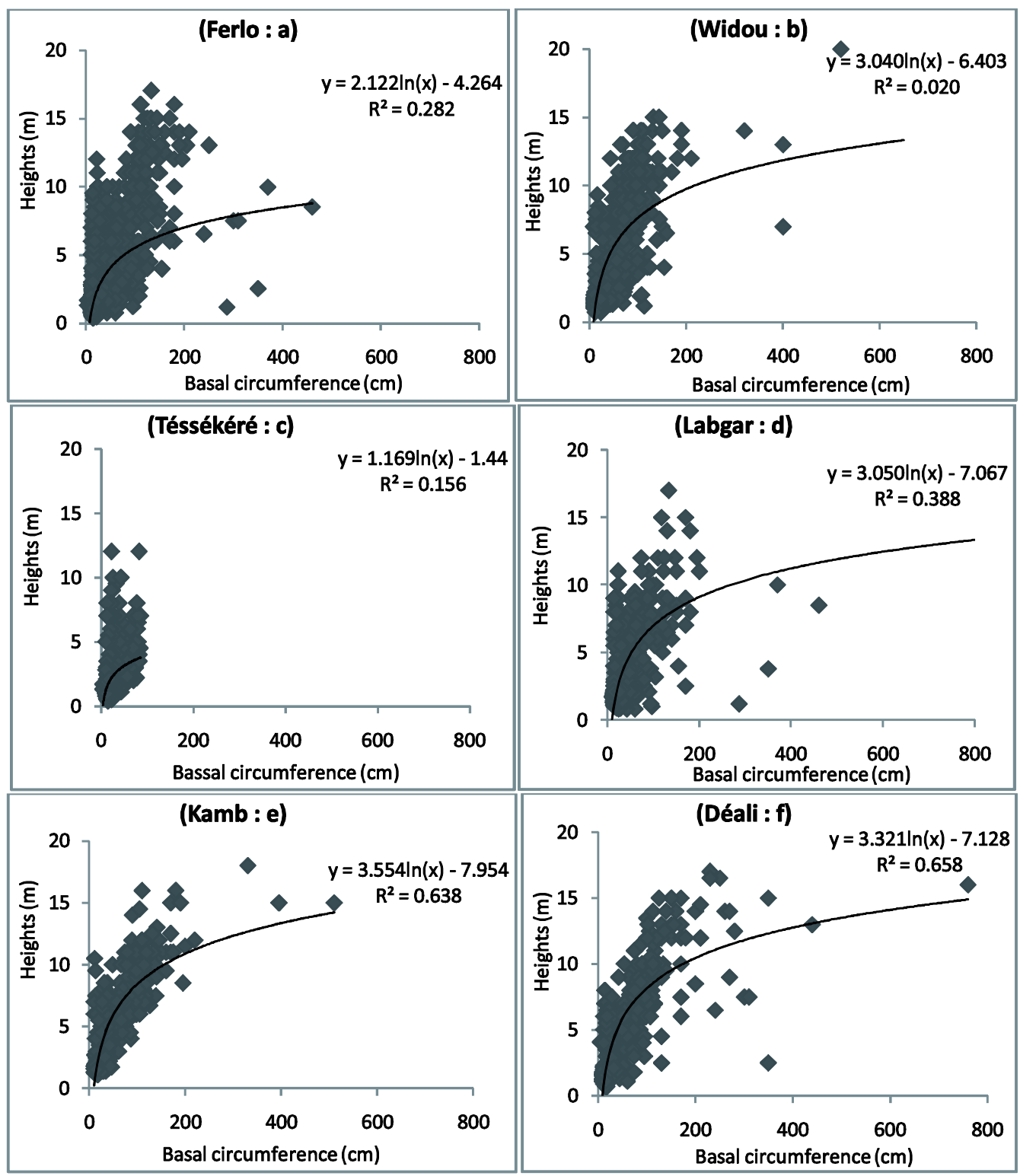

Figure 4. Regression lines describing the relationship between height and circumference for individuals surveyed.

extinction in the medium or long-term species threat exacerbated by an operation that fails to implement intervention measures to reverse this process [22,23].

Regarding the structural composition of populations and communities, the density of woody taxa is generally low in the study zone. There is also much inter-site variability, with higher densities in Widou and lower densities in Kamb. We find, however, that observed densities are higher in our particular study zones than in previously published work [14]. Between 1989 and 1998, density was found to range between 124 and 129 individuals per hectare, which is slightly lower than the density observed in this study of 180.22 individuals per hectare. However, densities observed in our analyses are lower than even older studies [3,5,24]. The abundance of certain species, like $C$. procera and $B$. senegalensis, agrees with data from [25]. According to [25], the progression of species that are supposedly resistant to drought does not seem to be inhibited by elevated rains.

The mean distance between individuals is relatively high in the south part of the study zone (Kamb and Déali) compared to the north (Widou, Téssékéré and Labgar). This pattern could be explained by an increase in agricultural activity in the southern Ferlo region. This low average distance between individuals, noted especially in the northern part of the zone, is not characteristic of degraded ecosystems [26-30]. It should be noted that the decrease in average distance between individuals was found to be $7.1 \mathrm{~m}$ according [4]. The theoretical density is also two times higher than the real density in each of 


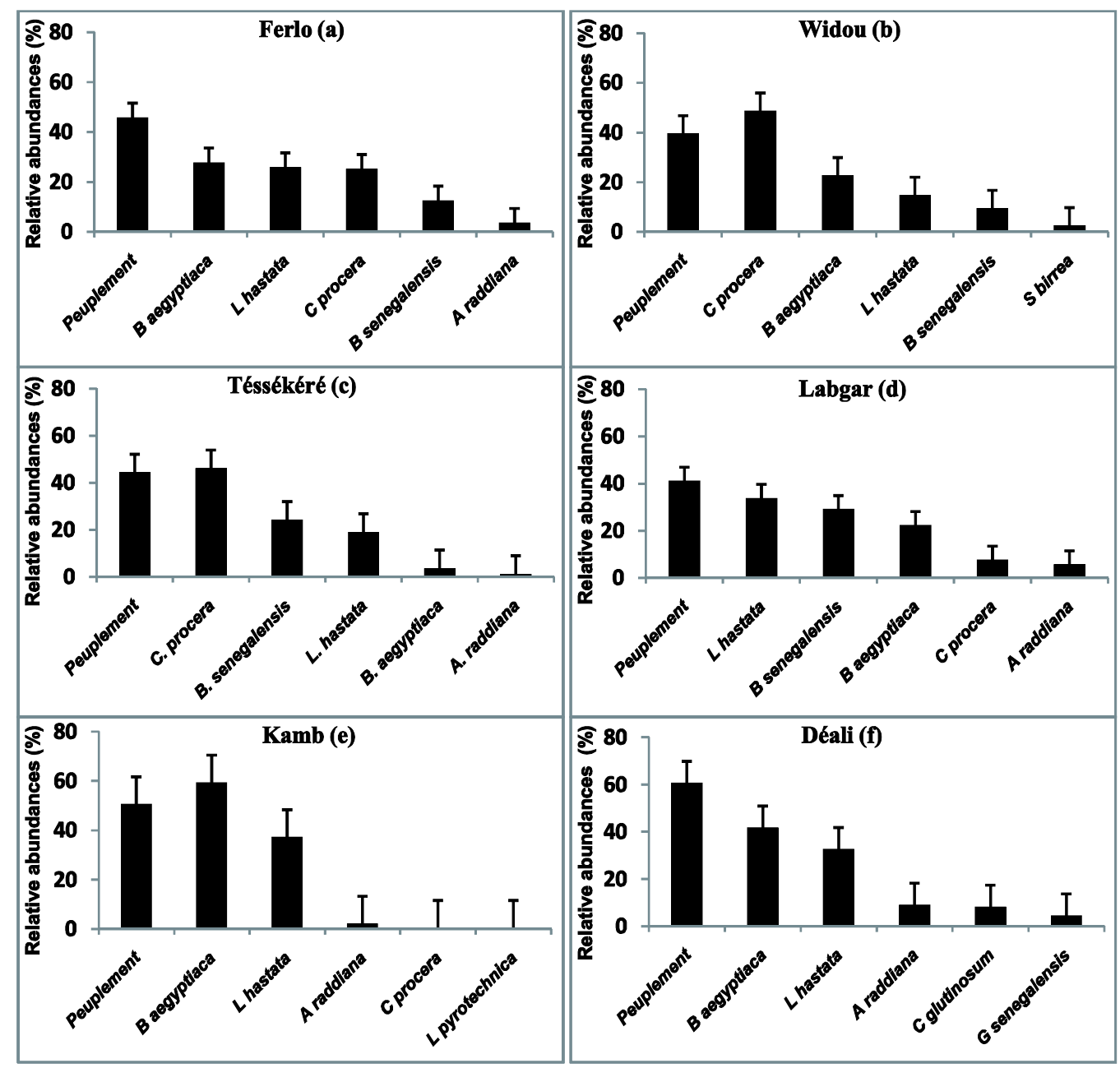

Figure 5. The distribution of young plants in the study sites.

the sites, with high coefficients of variation stipulating an aggregate distribution of individuals. Such an aggregate distribution has been shown in several studies conducted in the Ferlo zone [4,13,14,31].

The surface area is relatively low and varies between sites and species. It is highest in Widou and Labgar and lowest and statistically similar in Téssékéré, Kamb and Déali. Basal coverage is higher in Labgar than in Téssékéré despite the higher density found in Téssékéré.

This pattern could possibly be explained by the abundance of individuals with large trunks in Labgar. The woody populations in the study area are largely dominated by $B$. aegyptiaca whose rooting zone area is nearly double that of $A$. digitata, despite the size of the latter's trunk. In these areas, it seems that the high density of $B$. aegyptiaca compensates for the large trunk size of $A$. digitata, allowing for co-existence [32].

Crown cover is low in the study reason because of grazing activity that tends to depress the development of woody taxa $[33,34]$. It varies according to sites, with higher crown cover in Widou, Kamb and Déali and lower cover in Téssékéré and Labgar. Effectively B. aegyptiaca alone represents more than half of woody cover in Widou and Déali. In Kamb, B. aegyptiaca associates with $A$. raddiana in forming semi-joined crowns that cover approximately the same area despite lower densities.

The woody population is mainly constituted of individuals with a small size as seen in our results for the structure of the populations broken down by circumference class. The low representation of individuals with a circumference greater than $100 \mathrm{~cm}$ can be explained by charcoal production, wood for construction, and firewood in the region that favors high-circumference species, as well as using the foliar resources for livestock during the dry season including $C$. procera and $B$. senegalensis in the northern part of the zone, whereas the southern part of the region is dominated by B. aegyptiaca.

In general, the population structure according to circumference and height show a clear dominance of young individuals. Young plants are relatively abundant in the Ferlo, though they vary according to site and species. 


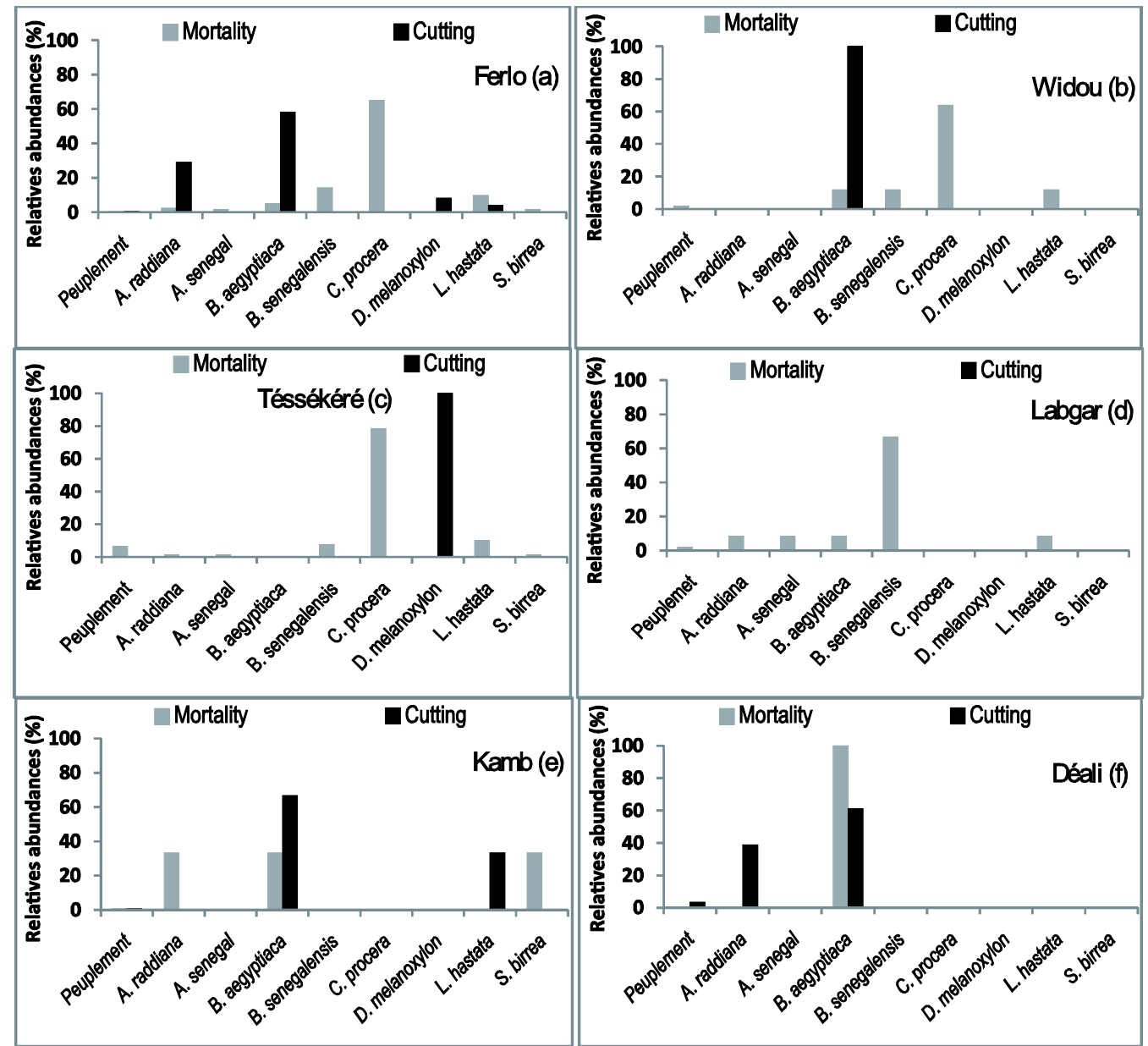

Figure 6. Mortality and human impact on woody populations of the study area.

Considering the entire study region, the young plants of B. aegyptiaca are the most abundant, followed by C. procera and $B$. senegalensis.

The considerable ability to regenerate found among $B$. aegyptiaca can be explained by their ability to maintain photosynthetic activity through the year [14]. Site-specific analyses reveal that regeneration rates are higher in the southern part of the Ferlo, where there are more adult individuals than in the north. This higher rate of regeneration is correlated with higher woody cover in the southern part of the region. This pattern is likely explained by patterns of higher precipitation in the southern part of the study zone. Woody cover offers favorable conditions for seeds to germinate and saplings to grow [4]. Species which generate better in the southern region are more dominant, except for in Labgar, which is dominated by young plants of L . hastata. In the north part of the zone, $B$. aegyptiaca is better at regenerating. In the southern part, the species with higher ability to regenerate also happen to be less palatable to livestock and have fewer ethnobotanical uses [9]. The regeneration of species in the Ferlo zone shows a gradual evolution accord- ing to these patterns.

The rate of human exploitation is relatively low for these populations in the Ferlo zone. In this area, human impacts are most often due to selective pruning for firewood and other cutting of useful species. Many of the species undergoing impacts from humans have important ethnobotanical uses [9].

\section{Conclusion}

The present study evaluated the structural diversity of woody taxa in the Ferlo region of the Sahel, in Senegal. This structural diversity is relatively low compared to other agroecological zones of Senegal. The dominance of woody species, such as $B$. aegyptiaca, $B$. senegalensis and $C$. procera shows that these taxa have developed resistance to the particularly harsh climate conditions of the Sahel as well as to human impacts. The study has also allowed for a corroboration of the idea that the vegetation of the Sahel is progressively evolving because it is dominated by shrubby taxa. We have also shown that the southern part of our study region is a transition between sylvo-pastoralism and the peanut-growing region 
of central Senegal. This southern zone is much impacted by human activity, especially agricultural activity.

\section{REFERENCES}

[1] L. E. Akpo, A. Gaston and M. Grouzis, "Specific Structure of a Sahelian Vegetation: Case of Wiidu Thiengoli (Ferlo, Senegal),” Bull. Mus. Natl., Paris, 1995, pp. 3952.

[2] A. Ba, "Evaluation des Revenus des Agropasteurs, leurs Demandes de Formation et d'Education, et Leurs Capacités Contributives: cas de l’Unité Pastorale de Bélèl Bogal dans le déPartement de Podor au Sénégal,” Ph.D. Dissertation, ENEA, Dakar, 2007.

[3] A. T. Diop, "Les ressources ligneuses de la zone sylvopastorale du senegal: Evolution, gestion et perspectives de developpement," Communication Présentée à l'Atelier Tenu à l’Université Cheikh Anta Diop de Dakar sur Forêt, Environnement et Développement du 22 au 26 mai 1989.

[4] L. E. Akpo and M. Grouzis, "Influence du couvert sur la regeneration de quelques especes ligneuses saheliennes (Nord Sénégal, Afrique Occidentale),” Webbia: Journal of Plant Taxonomy and Geography, Vol. 50, No. 2, pp. 247-263.

http://dx.doi.org/10.1080/00837792.1996.10670605

[5] J. Piot and A. Diakite, "Système de production d'elevage au senegal. Etude du couvert ligneux," Compte rendu de fin d'etude. C.I.T.: Nogent sur Marne, ISRA: DakarHann, 1983, p. 30.

[6] M. Miehe and Marburg, "Surveillance Continue de la Végétation dans le Périmètre Expérimental à Widou Thiengoly dans le cadre des projets sénégalo-allemands, 19812007. Dispositif expérimental, méthodes de suivi et perspectives d'évaluation," Atelier sur le transfert du patrimoine scientifique du PAPF, Dakar, Senegal, 6 June 2007, p. 26.

[7] A. Wane, V. Ancey and B. Grosdidier, "Les unités pastorales du Sahel sénégalais, outils de gestion de l'élevage et des espaces pastoraux. Projet durable ou projet de développement durable?” Développement durable et territoires [En ligne], Dossier 8: Méthodologies et pratiques territoriales de l'évaluation en matière de développement durable, 2006. http://developpementdurable.revues.org/3292

[8] G. Faye, P. L. Frison, S. Wade, J. A. Ndione, A. C. Beye and J. P. Rudant, "Etude de la saisonnalité des mesures des diffusiomètres scat: Apport au suivi de la végétation au sahel, cas du Ferlo au Sénégal,” Rev Télédétection No 10, 2011, pp. 23-31.

[9] K. Niang, "L'arbre Dans les Parcours communautaires du Ferlo-Nord (Sénégal),” Ph.D. Dissertation, FST/UCAD, 2009, p. 67.

[10] M. Diouf, “Caractéristiques fondamentales de la feuillaison d'une espèce ligneuse sahélienne: Acacia tortilis (forsk) hyane, variation selon les microsites topographiques du Ferlo (nord-Sénégal)," Ph.D. Dissertation, FST-UCAD, 2003, p. 103.

[11] P. Michel, "Les bassins des fleuves Sénégal et Gambie: étude géomorphologique,” Ph.D. Dissertation, Orstom, 3 tomes, 1973, p. 753.

[12] G. Boudet, "Manuel sur les pâturages tropicaux et les cultures fourragères,” $4^{\mathrm{e}}$ éd, Paris, Ministère de la coopération, Manuels et Précis d’Elevage No 4, 1984, pp. $1-254$.

[13] L. E. Akpo, F. Bada and M. Grouzis, "Diversité de la végétation herbacée sous arbre: Variation selon l'espèce ligneuse en milieu sahélien,” Candollea No 58, 2003, pp. 515-530.

[14] M. Diouf, L. E. Akpo, A. Rocheteau, F. Do, V. Goudiaby and A. L. Diagne, "Dynamique du peuplement ligneux d'une végétation sahélienne au Nord-Sénégal (Afrique de l'ouest),” J. Sci., Vol. 2, No. 1, 2002, pp. 1-9.

[15] J. Berhaut, "Flore du Sénégal, deuxième édition plus complète avec les forêts humides de Casamance,” 1967, p. 485.

[16] J. P. Lebrun and A. L. Stork, "Enumération des plantes à fleurs d'Afrique tropicale. Conservatoire et Jardin botaniques de Genève,” Vol. I, II, III, IV, 1991, 1992, 1995, 1997, pp. 249, 257, 341, 712.

[17] P. Wouters and V. Notelaers, "L'espace entre les arbres et la densité des peuplements,” Sylva Belgica No 106, p. 4.

[18] J. Rondeux, "La mesure des arbres et des peuplements forestiers," Les presses agronomiques de Gembloux, 1993, pp. 16-59.

[19] A. Aubreville, "Accord à Yangambi sur la nomenclature des types africaine de végétation,” Bois et Forêts des Tropiques No 51, 1957, pp. 23-27.

[20] J. Touffet, “Dictionnaire essentielle d'écologie,” Ouest France, 1982, p. 108.

[21] H. N. Fonton and P. Sagbo, "Modélisation des Distributions des Paramètres Dendrométriques d'une Espèce Ligneuse Dominante en Peuplement Naturel," Annals of Forest Science, Vol. 61, No. 6, 2004, pp. 545-549. http://dx.doi.org/10.1051/forest:2004049

[22] E. Semereab, J. Philippart and J. L. Doucet, "Evaluation de la Présence de Forêts a Haute Valeur Pour la Conservation Dans la Concession Forestière Attribuée à Gau Services (Cameroun) Selon le Concept Défini par le Principe du Forest Stewardship Council,” Nature + asbl, Gembloux, 2010, p. 57.

[23] A. Diallo, E. C. Agbangba, O. Ndiaye and A. Guisse, "Ecological Structure and Prediction Equations for Estimating Tree Age, and Dendometric Parameters of Acacia Senegal in the Senegalese Semi-Arid Zone-Ferlo," American Journal of Plant Sciences, No 4, 2013, pp. 1046-1053. http://dx.doi.org/10.4236/ajps.2013.45129

[24] H. Poupon, "Structure et dynamique de la strate ligneuse d'une steppe sahélienne au nord du Sénégal,” Orstom ed. (Etudes \& Thèses), Paris, 1980, p. 307.

[25] A. T. Diop, “Les ressources de l'aire pastorale de Tatki: Inventaire et étude du mode d'exploitation, propositions de plan d'aménagement et de gestion rationnelle,” LNERV, Dakar, 1987, p. 190.

[26] C. D. Diatta, "Flore et végétation ligneuse de la réserve de Ngazobil (Joal-Fadiouth) au Sénégal,” Ph.D. Dissertation, Université Cheikh Anta Diop, Dakar, 2006, p. 34.

[27] B. Toutain, L. Bortoli, D. Dulieu, Forgiarini, J. C. Menaut 
and J. Piot, "Espèces ligneuses et herbacées dans les écosystèmes sahéliens paturés de Haute-Volta,” ACC GRIZA (LAT), GERDAT, 1983, p. 124.

[28] M. Benoit, "La dune de Gondol. Dégradation d'un biotope ou histoire d'un paysage?” ORSTOM, Paris, Cah. Sci. Hum No 24, 1988, pp. 487-501.

[29] B. Sambou, A. Goudiaby, J. E. Madsen and A. T. Ba, "Etude comparative des modifications de la flore et végétation dans les forêts classées de Koutal et de l'Ile Kouyong (Centre-Ouest du Sénégal),” Journ. D’Agric. Trad. Et de Bota. Appl., nouvelle série, XXXVI No 1, 1994, pp. 87100.

[30] C. Vincke, "La dégradation des systèmes écologiques sahéliens. Effets de la sécheresse et des facteurs anthropiques sur l'évolution de la végétation ligneuse du Ferlo (Sénégal),” MFE, UCL-FSA/UEF, 1995, p. 82.

[31] A. Diallo, M. N. Faye and A. Guissé, "Structure des peu- plements ligneux dans les plantations d'Acacia senegal (L.) Wild dans la zone de Dahra (Ferlo, Sénégal),” Rev. Ecol., Terre et Vie No 66, 2011, pp. 415-427.

[32] I. Coly, L. E. Akpo, H. Dacosta, F. Diome and R. Malou, "Caractérisation agro-écologique du terroir de la Nema au Saloum (Sénégal): Les systèmes d'utilisation des terres et diversité du peuplement ligneux,” Journal des Sciences, No. 1, 2001, pp. 9-18.

[33] F. Chambris, "Dynamique des pâturages sahéliens: Influence des pluies du substrat et de l'exploitation animale. Exemple du Ferlo septentrionale, Sénégal, 6 années d'observation à Labgar,” Daa, Ensa, Montpellier, 1988, p. 68.

[34] J. Poissonnet, F. Chambris and I. Toure, "Equilibre et déséquilibre des phytocénoses sahéliennes. Influence de la pluviosité annuelle et de la proximité des points d'eau," In E. Le Floc'h, M. Grouzis, A. Cornet and J. C. Bille, Eds., L'aridité: Une contrainte au développement, Orstom (Coll. Didactiques), Paris, 1992, pp. 283-296. 